\title{
US Army Aviation Medicine
}

Maj S E Piwinski* ${ }^{*}$ MD, MPH.

Maj J G Mills, DO, MPH.

Col El R Jenkins, MD, MPH.

In February 1912, the Surgeon General of the United States Army prepared a special preliminary physical examination for candidates who were to receive instruction in the Aviation Section of the Signal Corps. This examination and those devised over the next four years were too demanding and few candidates could pass. In response to the need to revise medical standards for aviators, Colonel Theodore Charles Lyster, "the Father of Aviation Medicine in America", chaired a group of aeromedical experts in 1916 for that purpose. Then in 1917, Colonel Lyster and a medical team visited American squadrons in France where they found an unsatisfactory aviation medical support program. They found the pilots in poor physical condition, low morale, high flying accident rates, and Army aircraft accident fatalities three times greater than from enemy action. These problems made the team realise that a medical officer specifically trained to recognise and cope with the problems of the aviator was needed. After the team returned to the United States, a program of selecting and training flight surgeons was instituted at the Mineola Laboratory. By June 1918, it was functioning as a school for training flight surgeons. The first graduates of the school were sent overseas to provide aviation support to the air squadrons of the American Expeditionary Force in August 1918. After the arrival of this group, flying accidents and deaths were reduced and commanding officers were pleased to give full credit to the work of these trained flight surgeons.

US Army aviation and aviation medicine lay dormant during the 1920's and 1930's and flourished again just prior to and during WW II. On June 201941 , a separate air arm - the Army Air Force - was created, along with separate medical support. In the spring of 1942, the concept of using light aircraft organic to field artillery to spot targets was being tested at Fort Sill, Oklahoma. On June 6, 1942, the War Department approved organic aviation for field artillery and Army Aviation was born. Modern day aviation traces its roots to these small single-engined observation aircraft.

In 1950, LTC R M Harrison, one of the few Army Air Force medical of ficers who remained with the Army, was developing what could be considered an Army Aviation Medicine Program. During the Korean War, the Army

* Maj S E Piwinski is Chief Education and Training Department, US Army Aeromedical Center, Fort Rucker, AL. began sending medical of ficers through the Air Force Basic $\overrightarrow{0}$ Aviation Medicine Course at the US Air Force School of Aviation Medicine, Randolph AFB, Texas. Col Spurgeonce $\mathrm{H}$ Neel was the first graduate of this program in March? 1951. The USAF and USN trained Army flight surgeons until July 1963 when Headquarters, USCONARC, directed that a basic course in aviation medicine be established at the $\vec{\omega}$ US Army Aviation School, Fort Rucker, Alabama. This? year, the aviation medicine training program at Fortc Rucker will be redesignated the US Army School Aviation Medicine'.

Since the development of the US Army's own flig $\rightarrow$ surgeon course in 1963, fewer Army medical officers affec being trained by our sister Services, although an occasioral? reserve component physician transfers his allegiance from the Air Force or the Navy to the Army. To date, a totalgf 498 physicians have earned their US Army flight surgeoms $s$ wings in this manner.

The present Army Aviation Medicine Basic Courseds seven and one-half weeks long and divided into three phases to facilitate attendance by physicians from the reserveo components who cannot leave their practices for twoo months. Since 1963, a total of 1,562 physicians, physician's assistants, and medical students from the US Army, the US $\overrightarrow{\vec{P}}$ Coast Guard, the US Air Force, and nine allied nations 3 have earned their flight surgeon's wings at Fort Rucker.

Since 1974, 29 aeromedical physician's assistants have? graduated and are generally being used as physician $\exists$ extenders, especially for flying duty medical examinations. Though only possessing bachelor's degrees, the physician's assistants are required to complete the same course as the physicians and have generally had few academic problems.

Medical students were first admitted to the flight surgeon: course in 1980 to expose them to aviation medicine early in 3 . their training in the hopes of influencing later careero decisions. Only half of the medical students who have earned flight surgeon wings have returned to active aviationo duty after their internships. Presently, medical students who take the course are being required to serve eighteen months of aviation duty on completion of their internship.

Our foreign graduates have rarely had difficulty in the flight surgeon's course due to high motivation and interest, $\stackrel{\sim}{\sim}$ and extensive screening by their respective governments. English language proficiency. testing by the US State Department and the US Army have prevented the 
development of academic problems due to poor language skills.

In the structure of our flight surgeon course, phases one and two consist of a review of the basic medical sciences pertinent to aviation medicine and an introduction to the medical standards used for initial screening and retention of US Army aircrew members. Phase three consists primarily of 15 hours of flight training in the TH-55A, the primary rotary wing trainer of the US Army Aviation School. Our students use the same syllabus as all initial entry pre-solo student pilots and a final flight line score is given to all student flight surgeons by an instructor pilot from the Department of Evaluation and Standards. This score counts as 15 per cent of the student's final grade for the flight surgeon's course. See Table 1 for a further description of our curriculum.

\section{Table 1}

\section{Curriculum of the US Army Flight Surgeon's Course} Phase I - Basic Sciences and Introduction to Aviation Medicine Ophthalmology - 19 hours: Anatomy, neurophthalmology, visual standards, policy on acuity and motility problems, examination techniques, laser hazards, and night vision lab.

Otolaryngology - 13 hours: Anatomy, physiology, barotrauma, hearing loss, disorientation, and motion sickness.

Aviation Medicine - 18 hours: Altitude physiology, dysbarism, acceleration toxicology and fatigue.

Psychiatry - 10 hours: Stress management, alcohol and drug abuse policy, and adaptability ratings.

Waiver and Review Policy - 10 hours: Discussion of the U.S. Army regulations pertaining to initial selection and retention of aircrew.

Phase II - Basic Sciences and Introduction to Aviation Medicine Aviation Life Support Equipment -4 hours: Helmets, flight suits, and MOPP gear.

Temperature Extremes -4 hours: Injuries in hot and cold environments.

Aircraft crash investigation -16 hours: Techniques of investigation and crashworthy features of aircraft.

Aircraft Crash Pathology -5 hours.

Internal Medicine -14 hours: Policy concerning problems in neurology, cardiology, and general internal medicine.

Aircraft Systems - 18 hours: Aerodynamics and navigation.

\section{Phase III - Flight Training}

Fifteen hours of in-aircraft training to the pre-solo checkride. Academic Subjects - 20 hours: Chemical, biologic, and nuclear defense, the Federal Aviation Administration medical regulations, air traffic control procedures, preventive medicine, and air evacuation.

One key to providing expert instruction to our students is the liberal use of instructors from outside the US Army School of Aviation Medicine. One half of our instructors come from organizations such as the Armed Forces Institute of Pathology, the Office of the Surgeon General, Walter Reed Army Medical Center, Walter Reed Army Institute of Research, the US Army Aeromedical Research Laboratory, the US Army Safety Center, the US Army Research Institute of Environmental Medicine, and the University of Wisconsin. In the past, we have been successful at recruiting reserve component and active duty specialists in fields such as Otolaryngology, Cardiology, Neurology and Psychiatry to attend our course and later return as instructors in their fields of expertise. Use of visiting experts has been a highly successful method of providing the medical expertise that a relatively small post hospital such as Fort Rucker's Lyster US Army Community Hospital does not possess. The contributions of these instructors cannot be overlooked and their dedication continues to make the US Army Flight Surgeon's Course one of the most popular and respected training schools in the US Army.

In recent years, more emphasis has been placed on integrating our graduates into their unit's command structure. Due to their inexperience with military life and their high rank at a relatively young age, many flight surgeons have lacked credibility with the line officers of their units. To counter this, military discipline is emphasized in the course and urine drug screening for all students is conducted in accordance with US Army regulations.

Other highlights of our course include ejection seat training, an altitude chamber ride to 35,000 feet, and के flight using night vision goggles. We recently begafe underwater egress training in the US Navy 9D5 Helo $\rightarrow$ Dunker at Pensacola Naval Air Station, Florida. Classe such as the Helo Dunker provide realistic training for oum students and, though quite physically demanding, hav proven to be immensely popular. In the future we hope to schedule the intensive 10 day US Army Air Assault Course

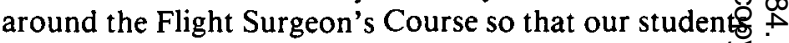
may attend both. In addition to learning air assaur. techniques such as rappelling from helicopters, length runs and morning inspections are integral to the coursè. We expect such training to provide greater understanding of Army aviation battalion operations and to instil a greater sense of accomplishment and pride in our students.

The ideal flight surgeon is an officer in the US Army who is an integral member of the aviation unit commander's staff. Discipline, military courtesy, and rigorous and realistic training facilitate achievement of this goal. Army flight surgeons are charged with conserving the fighting of aviation units through preventative medicine measures including identification of specific presentable causes of aircraft accidents, prevention of communicable diseases, health surveillance of aircrew members, and unit education and training. Though little discussed in the past, the flight surgeon is also charged with the rapid and competent emergency medical care of aircrew members injured in battle or training. Our ultimate goal is to provide Army aviation with a cadre of dedicated and competent officers who willingly serve their comrades in war and in peace.

\section{REFERENCE}

1. U.S. Army Special Text 1-105-8 The Army Flight Surgeon's Manual, U.S. Army Aeromedical Center, Fort Rucker, Alabama, 1976; pp. 51-53. 